DOI https://doi.org/10.32837/app.v0i65.307

УДК 316.77

I. Ф. Новосельський

ORCID ID: https://orcid.org/0000-0002-5272-0822

аспірант кафедри політичних інститутів та процесів

ДВНЗ «Прикарпатський національний університет імені Василя Стефаника»

\title{
ПОЛІТИКО-ПРАВОВІ ЗАСАДИ ФУНКЦІОНУВАННЯ НОВИХ МЕДІА: СВІТОВИЙ ДОСВІД ТА УКРАЇНА
}

Поширення інтернету, доступність інформаційних ресурсів створили можливості для появи принципово нових медіа, вплив яких порівняно із традиційними засобами масової інформації (далі - 3МI) невпинно зростає. Про це свідчать дані звіту Digital 2020, згідно з якими на початок 2020 р. порівняно із 2019 р. кількість інтернет-користувачів у світі зросла до 4,54 млрд. (+7\%), аудиторія соціальних мереж - до 3,8 млрд. (+9\%). Отже, натепер онлайн-технологіями користуються 60\% світового населення (Digital 2020, 2020). Водночас швидкий доступ та поширення новинного контенту, високий рівень інформаційної активності, стрімке збільшення впливу соціальних медіа на суспільні настрої створюють ризики використання маніпуляційних технологій, здійснення пропаганди та ведення інформаційних воєн. В умовах розвитку і трансформації інформаційного суспільства правовий статус нових медіа потребує законодавчого закріплення.

Вивченню нових медіа як окремого сегмента медіаринку приділяли увагу Т. Барр, М. Кастельс, Н. Крістенсен та ін. Сучасний інформаційний простір, питання правового регулювання мережі Інтернет стали предметом досліджень О. Баранова, 3. Григорової, К. Єфремової, Д. Грибанова, Г. Кашуби, М. Чабаненко. Окремі законодавчі аспекти медійного поля України досліджували О. Давидюк, І. Людвик, Ю. Нестеряк, Г. Почепцов, Д. Проценко, Д. Тупчієнко й ін.

Метою дослідження є вивчення специфіки міжнародного досвіду правового унормування нових медіа та з'ясування особливостей політико-правового регулювання медійного простору в сучасній Україні.

Зростання ролі інтернет-технологій як найбільш впливового джерела інформації відбулось і в сучасній Україні. Так, кількість інтернет-користувачів досягла 27,46 млн., а коефіцієнт проникнення інтернету становить 63\%. Водночас число українців, які користуються соціальними мережами, становить 19 млн., показник проникнення мереж - 43\% (Digital 2020, 2020).

Стрімкий розвиток онлайн-медіа в Україні розпочався у квітні 2000 р. і пов'язаний із заснуванням онлайн-видання «Українська правда» як реакції на придушення свободи слова та цензури. Уже декількома місяцями пізніше нові медіа стали серйозними конкурентами традиційних, до середини 2001 р. їхня кількість збільшилась до 40. Специфікою цих онлайн-видань був конфронтаційний характер новинного й аналітичного матеріалу щодо існуючої влади. Усе це вимагало нормативного упорядкування діяльності онлайн-медіа у сфері інтернет-відносин.

Необхідно зазначити, що в Україні неодноразово ініціювалась підготовка проєктів нормативно-правових актів із питань регулювання правовідносин під час поширення інформації в українському сегменті Інтернет. Такими проєктами стали Указ ПУ від 31 липня 2000 р. № 928 «Про заходи щодо розвитку національної складової глобальної інформаційної мережі Інтернет та забезпечення широкого доступу до цієї мережі в Україні», наказ Міністерства транспорту і зв'язку від 27 квітня 2005 р. № 153 «Про затвердження Порядку проведення державної реєстрації електронних інформаційних ресурсів», розпорядження Кабінету Міністрів України від 18 лютого 2009 р. № 185-р «Про затвердження орієнтовного плану законопроєктних робіт на 2009 р.», проєкт закону України «Про концепцію державної інформаційної політики» від 13 жовтня 2010 р. Однак усі зазначені ініціативи, зважаючи на суспільний резонанс, не набули чинності. 
Водночас більшість інтернет-3МІ виступають проти обов'язкової реєстрації, уважають застосування такого підходу наступом на свободу слова та спробою поширити державний контроль над інформаційною діяльністю. За добровільну недержавну реєстрацію виступає Незалежна медіапрофспілка України (далі - НМПУ). Так, ще у 2012 р. НМПУ закликала медійні організації до дискусії щодо необхідності ведення реєстру інтернет-3МІ на добровільних засадах. Проте такий підхід вимагає від власників сайтів, що поширюють масову інформацію, високого рівня свідомості та готовності брати на себе відповідальність (Конах, 2013). Додатковою перешкодою на шляху вирішення проблеми залишається небажання самих інтернет-3МI виробити солідарну позицію стосовно регулювання їхньої діяльності.

Сучасну правову базу медіапростору України становлять відповідні норми Цивільного кодексу України, закони України «Про телекомунікації», «Про авторське право і суміжні права», «Про інформацію», «Про друковані засоби масової інформації (пресу) в Україні», «Про телебачення і радіомовлення», «Про Національну раду України з питань телебачення і радіомовлення», «Про інформаційні агентства», «Про рекламу», «Про телекомунікації», «Про радіочастотний ресурс», «Про захист персональних даних», «Про доступ до публічної інформації тощо.

Українське законодавство в основному регулює діяльність «класичного» телебачення (далі - ТБ) (ефір, супутник, кабель). Водночас відсутність системного регулювання відносно «нових» способів поширення ТБ (IPTV, ОТT), відео на замовлення і платформ спільного доступу до інформації актуалізує необхідність прискорення регуляції норм медійної галузі для функціонування нових медіа. До того ж Україна має міжнародні зобов'язання щодо закріплення на законодавчому рівні комплексу правових норм у галузі аудіовізуальних медіа, який би відповідав європейським стандартам та сучасному рівню технологічного розвитку, спростив державне регулювання галузі, визначив ефективні та сучасні засади захисту прав споживачів на вільне отримання інформації, а також законні механізми визначення й обмеження шкідливого контенту (згідно з нормами Директиви Європейського парламенту та Ради 2010/13/ЄС про аудіовізуальні медіапослуги від 10 березня 2010 р., зі змінами, внесеними Директивою (СС) 2018/1808 від 14 листопада 2018 р. (Directive (EU), 2018).

Зазначимо, що в Україні довгий час не існувало жорстких обмежень діяльності інтернет-ресурсів. Гарантований державою правовий захист від зловживань мав несистемний характер. Нечисленні спроби унормувати спірні питання щодо понятійного апарату медіасфери (проєкт закону «Про внесення змін до деяких законодавчих актів України щодо протидії загрозам національній безпеці в інформаційній сфері» № 6688 від 12 липня 2017 р.), навіть неоднозначно сприйняті суспільством спроби криміналізувати дифамацію (проєкт закону «Про внесення змін до Кримінального та Кримінально-процесуального кодексів України» № 11013 від 19 липня 2012 р.) не впроваджені в політичну практику.

Тому очікуваною спробою гармонізації українського законодавства з вропейським правом стала реєстрація у Верховній Раді України проєкту закону «Про медіа» № 2693 від 27 грудня 2019 р. У суспільному дискурсі він відомий як «закон про дезінформацію». Новизною законопроєкту стало термінологічне коригування поняття «засоби масової інформації» і введення в обіг категорій «медіа», «дезінформація». Нормами документа фіксується питання кримінальної відповідальності за поширення дезінформації, пропонується запровадження інституту нагляду за достовірністю інформації на чолі з Уповноваженим 3 питань інформації, введення індексу довіри до поширювача масової інформації на підставі відповідності 3МІ визначеним критеріям. Також зафіксована система штрафів онлайн-медіа від 5 до 25 тис. грн, для платформ суспільного доступу - від 45 до 355 тис. грн (станом на 2020 р.), які повинні стимулювати розроблення ефективних алгоритмів для виявлення порушень та реагування на них (Про медіа, 2019).

Вищезгаданий законопроєкт містить дуже неоднозначні норми, які свідчать про ризики небезпечного рівня державного втручання в журналістську діяльність і обмеження свободи слова через створення механізмів контролю за інформаційним простором (Огляд основних положень, 2019). Викликають дискусії і норми щодо принципів прозорості структури власності онлайн-медіа та контролю за поданням звітності, норм щодо регулювання мовлення 
громад. Тому за рекомендаціями фахівців Ради Європи законопроєкт направлений на доопрацювання до Комітету з питань гуманітарної та інформаційної політики.

Допомогти оцінити якість запропонованих законопроєктів за чітко визначеними критеріями, спираючись на засади прав людини, має Індекс правового регулювання відносин онлайн-простору, над створенням якого працює ГО «Інтерньюз-Україна» у співпраці із ключовими медіаюристами. Ця методика надасть змогу громадянському суспільству послідовно моніторити підходи та пропозиції щодо функціонування онлайн-простору та швидко реагувати на нові законодавчі ініціативи, що здатні підсилити вільний розвиток інтернету та цифрові права користувачів.

Аналіз сучасних міжнародних правових норм та рекомендацій щодо діяльності конвергентних технологій дозволяє виділити умовно східну та західну моделі у сфері правового регулювання онлайн-медіа. Для першої характерний домінантний державний контроль над всіма правовідносинами в інформаційній сфері, наявність певного виду премодерування інформаційних ресурсів у межах політичної ідеології країни, мінімізація або відсутність саморегулювання відносин учасниками інформаційної діяльності. Західна модель грунтується на встановленні розумного балансу між нормативно-правовою базою и інструментами саморегуляції, закріпленні за державою регулювання найважливіших положень, застосуванні принципу відповідальності як до офлайн, так і до онлайн-ресурсів (Конах, 2012).

Водночас зауважимо, що в рамках західної моделі можна виділити два підходи щодо визначення рівня впливу держави на медійний простір: умовно назвемо їх «держава-модератор» та «держава-гарант». Звернімося до досвіду правового регулювання реєстраційних засад ЗМІ та пов' язаного із цим впливу держави на функціонування медіа в деяких країнах.

Законодавство Угорщини надає повноваження державі контролювати медійний контент, визначає обов' язком електронних медіа надання точного новинного контенту щодо державних справ на різних рівнях управління, накладати штрафи і припиняти діяльність або взагалі закривати 3МІ на підставі певних нечітко визначених принципів. Збільшити свій вплив угорська влада намагалась і через законодавче закріплення податку на послуги інтернету. Однак у результаті мітингів і суспільного резонансу законопроєкт було відкликано (Hungarians stage, 2014). У 2019 р. Франція також спробувала запровадити оподаткування Google, Apple, Facebook та Amazon (GAFA), але у 2020 р. призупинила оподаткування цифрових послуг через неможливість компромісної позиції щодо оподаткування електронних послуг на рівні країн Європейського Союзу. Незважаючи на європейський досвід, у сучасній Україні ініціатива ведення податку на додану вартість на послуги західних корпорацій (Google, YouTube, Facebook, Apple, Adobe, Netflix) може бути підтримана законодавчо (Про внесення змін до Податкового кодексу, 2019). Проте занепокоєння спричиняє посилання розробників на досвід держави-агресора та можливі ризики підвищення вартості цифрових товарів і послуг для українських користувачів або навіть виходу Google з національного ринку.

Посилення ролі державного регулятора в діяльності 3МІ спостерігаємо в Польщі, Чехії, Сербії. Серед негативних аспектів даного підходу необхідно виділити залежність медіа від змін політичного ландшафту, збільшення урядового контролю над інформаційним простором, застосування методів фінансового тиску, процеси олігархізації медіа, підвищення непрозорості медіавласності.

У Франції та Великій Британії простір нових медіа регулюється нормами щодо діяльності традиційних 3МІ і не потребує окремого законодавства. Тут «держава-гарант» створює умови для правової саморегуляції ЗМІ на основі існуючого законодавства. Окремого закону про медіа не існує і в Німеччині. Правовою основою роботи ЗМІ виступає Конституція Федеративної Республіки Німеччина, яка розглядає свободу преси та свободу слова як основоположні права всіх громадян. Необхідність для створення окремого правового поля для мережі Інтернет визнається нелогічною і у Сполучених Штатах Америки (далі - США).

Абсолютно інший підхід до питання діяльності мережевих засобів масової інформації розглядає східна модель. Так, у Китайській Народній Республіці електронні 3МІ зобов'язані здійснювати державну реєстрацію, за допомогою якої можна знайти інформацію про автора новинного контенту та легально видалити будь-яке повідомлення з популярних сервісів або 
вебсторінок на сайтах без судового рішення. Посилений контроль влади щодо медіапростору законодавчо закріплений у Росії та Туреччині, де порядок денний формується схваленими владою мейнстрімними медіа в чітко визначених ідеологічних рамках. Водночас незалежні медіа стикаються з урядовими тисками, соціальні мережі охоплені фабриками ботів. Отже, зазначаємо здатність авторитарних режимів інструменталізувати можливості соціальних медіа, беручи останні під контроль.

На тлі зростання впливу соціальних медіа однією з актуальних проблем залишається боротьба з недостовірною інформацією. В ухваленому країнами Свропейського Союзу (далі ЄC) «Плані заходів щодо забезпечення безпечного користування Інтернетом» (1998 р.) визначаються методи протидії розповсюдженню протизаконного контенту в мережі Інтернет. Усе жорсткішу позицію щодо відповідальності в медійній сфері, закріплену в документі «Рекомендація Комітету міністрів державам-членам про роль та обов' язки інтернет-посередників» (2018 р.), також займає Рада Європи.

Для регулювання поширення нелегального контенту, що може підірвати довіру до цифрового середовища та становити загрозу для його подальшого розвитку, країни ЄС та інтернет-платформи активізували свої дії для вирішення цієї проблеми. Так, Європейським Союзом спільно з Facebook, Twitter, Youtube, Microsoft був розроблений «Кодекс поведінки щодо мови ворожнечі в Інтернеті», яким встановлено обов' язок розглядати скарги щодо нелегального контенту протягом 24 годин (European Commission, 2016). Яскравим прикладом зусиль урядів із регулювання пропаганди, що поширюється в соціальних мережах, є німецький закон проти висловлювань ворожнечі, відомий як NetzDG, у якому закріплена система штрафів проти вищезгаданих кампаній до 58 млн. доларів США в разі ігнорування видалення постів, що порушують авторські права (Network Enforcement Act, 2017).

Установлення спільних медійних правил та законодавчого регулювання інтернету вимагає активне переміщення виборчих кампаній у соціальні мережі. Так, за час парламентської кампанії 2019 р. в сучасній Україні партії лише у Facebook витратили більше мільйона доларів США й опублікували понад 40 тисяч рекламних дописів (Закони для соцмереж, 2019). У рамках світових тенденцій ці вибори підтвердили, що проблемою соціальних мереж залишаються маніпуляції та недостовірна реклама через відсутність дієвої системи правового унормування.

Для вирішення питання щодо немаркованої реклами деякі фахівці пропонують законодавчо закріплене видання дозволу на рекламу лише верифікованим особам (як у США) або офіційним групам підтримки (як у Чехії та Словаччині). Уважаємо, що для подолання поширення маніпуляцій у Facebook чи Google українська держава повинна ініціювати добровільну співпрацю на основі конкретних законодавчих рішень та налагодження контактів із впливовими мережами та платформами.

Водночас спроби держав протидіяти цим загрозам часто створюють більш серйозні ризики для свободи вираження поглядів онлайн. Ідеться, зокрема, про блокування та фільтрування онлайн-контенту, координовані кампанії з поширення дезінформації, використання тролів і ботів, несанкціонований збір персональних даних, надсилання фішингових листів, злам облікових записів для залякування громадських активістів, практику «блекаутів» (вимкнення Інтернету в усій країні) під час виборів, для попередження чи припинення протестів.

Країни з авторитарними режимами під виглядом боротьби 3 пандемією продовжують наступ на демократичні свободи громадян. Зокрема, Китай продовжив застосування таких сумнівних з погляду демократичних цінностей технологій для трекінгу, як дрони і додаток Alipay Health Code, який передає дані до поліції. Іран використовує додаток AC19, який, на думку фахівців, просто збирає дані про переміщення громадян. Використання даних для вистежування та контролю за COVID-19 в Україні черговий раз засвідчило відсутність культури захисту персональних даних у державі (Володовська, 2019).

Отже, проведений аналіз дозволяє зробити такі висновки. Дослідження підтвердило наявність розгалуженого законодавства на рівні європейських країн, яке регулює функціонування конвергентних медіа як за допомогою спеціальних нормативних актів, так і в руслі існуючих традиційних правових норм. Однак проблемним аспектом політико-правового 
функціонування медійного простору залишається відсутність у країнах-членах ЄС узгодженого та послідовного підходу до видалення нелегального контенту в діяльності нових медіа.

Правове регулювання останніх відбувається в рамках умовних «східної» та «західної» моделей. Перша відрізняється домінантним контролем із боку держави над медіапростором та інформаційними ресурсами, мінімізацією саморегулювання відносин учасниками інформаційної діяльності. Друга грунтується на дотриманні принципів відкритості, доступності, свободи обміну інформацією та закріплює за державою право регулювати та встановлювати розумний баланс між нормативно-правовою базою й інструментами саморегуляції.

Розгляд західної моделі дозволив виділити два підходи щодо законодавчо визначеного впливу держави на функціонування 3МI. У рамках підходу «держава-модератор» констатується залежність медіа від змін політичного ландшафту, збільшення урядового контролю над інформаційним простором, застосування методів фінансового тиску, процеси олігархізації медіа, підвищення непрозорості медіавласності (Угорщина, Чехія, Польща, Сербія). Другий підхід «держава-гарант» закріплює рекомендаційний характер норм діяльності конвергентних медіа та мінімізує втручання держави (Німеччина, Франція, США).

Аналіз чинного законодавства України свідчить, що правове забезпечення діяльності 3МI залишається суперечливим. Нормативна база щодо діяльності 3МI має досить розгалужену систему законів, наявні наміри узгодити їі із законодавством європейських країн відповідно до низки зобов' язань. Проте відсутність дієвих механізмів захисту національного медіапростору України та побудови інформаційного середовища, здатного протистояти загрозам інформаційної безпеки та пропаганди в соціальних медіа, актуалізує необхідність національного регулювання відносин в Інтернеті.

\section{Лimepamypa:}

Володовська В. Заборони та свободи в інтернеті: як виглядатиме Декларація цифрових прав людини. Zmina. 2019. URL: https://zmina.info/articles/zaboroni_ta_svobodi_v_interneti_jiak_vigljiadatime_ deklaracijia_cifrovih_prav_lijudini/ (дата звернення: 25.12.2019).

Закони для соцмереж: як протидіяти маніпуляціям в інтернет-просторі. ЦЕДЕМ. 2019. URL: https://cedem.org.ua/news/zakony-dlya-sotsmerezh/ (дата звернення: 25.04.2020).

Конах В. Інтернет-ЗМІ в Україні: проблеми визначення нормативно-правового статусу та врегулювання діяльності : аналітична записка. НICД. 2013. URL: http:/ /old2.niss.gov.ua/articles/1085/ (дата звернення: 13.05.2020).

Огляд основних положень законопроєкту «Про дезінформацію» та попередні висновки IMI. Iнститут масової інформаціï. 2019. URL: https://imi.org.ua/monitorings/oglyad-osnovnyh-polozhenzakonoproyektu-pro-dezinformatsiyu-ta-poperedni-vysnovky-imi-i31315 (дата звернення: 15.05.2020).

Про внесення змін до Податкового кодексу України щодо оподаткування податком на додану вартість електронних послуг, що постачаються нерезидентами фізичним особам, місце постачання яких розташовано на митній території України : проєкт закону України від 19 грудня 2019 р. № 2634. URL: http://w1.c1.rada.gov.ua/pls/zweb2/webproc4_1?pf3511=67703 (дата звернення: 25.04.2020).

Про медіа : проєкт закону України від 27 грудня 2019 p. № 26937. URL: https:/ /w1.c1.rada.gov.ua/pls/ zweb2/webproc4_1?pf3511=67812 (дата звернення: 15.04.2020).

Digital 2020: Global digital overview. URL: https://datareportal.com/reports/digital-2020-global-digital-overview (дата звернення: 15.05.2020).

Directive (EU) 2018/1808 of the European parliament and of the Council of 14 November 2018. URL: https:/ / eur-lex.europa.eu/legal-content/EN/TXT/?uri=celex:32018L1808 (дата звернення: 19.04.2020).

European Commission and IT Companies announce Code of Conduct on illegal online hate speech. URL: https:/ / ec.europa.eu/commission/presscorner/detail/en/IP_16_1937 (дата звернення: 19.04.2019).

Hungarians stage Budapest protest against internet tax. BBC news. URL: https://www.bbc.com/news/ world-europe-29783253 (дата звернення: 13.05.2020).

Network Enforcement Act (Netzdurchsetzunggesetz, NetzDG). Federal Law Gazette. I. P. 3352 ff. Valid as from 1 October 2017. URL: https:/ / germanlawarchive.iuscomp.org/ ?p=1245 (дата звернення: 18.04.2019).

\section{References}

Volodovska V. (2019). Zaborony ta svobody v interneti: yak vyhliadatyme Deklaratsiia tsyfrovykh prav liudyny [Prohibitions and freedoms on the Internet: what the Digital Declaration of Human Rights will look like] / Zmina. Retrived from: https://zmina.info/articles/zaboroni_ta_svobodi_v_interneti_jiak_vigljiadatime_ deklaracijia_cifrovih_prav_ljiudini. [in Ukrainian] 
Zakony dlia sotsmerezh: yak protydiiaty manipuliatsiiam $\mathrm{u}$ internet-prostori [Laws for social networks: how to counteract manipulations in the Internet space] (2019). Retrived from: https://cedem.org.ua/news/ zakony-dlya-sotsmerezh. [in Ukrainian]

Konakh V.K. (2013). Internet-ZMI v Ukraini: problemy vyznachennia normatyvno-pravovoho statusu ta vrehuliuvannia diialnosti: analitychna zapyska [Internet media in Ukraine: problems of determining the legal status and regulation of activities: an analytical note] / NISD, 2013. Retrived from: http://old2.niss.gov.ua/ articles/1085. [in Ukrainian]

Ohliad osnovnykh polozhen zakonoproektu "Pro dezinformatsiiu" ta poperedni vysnovky IMI [Review of the main provisions of the draft law "On Disinformation"; and preliminary conclusions of IMI] (2019). Retrived from: https://imi.org.ua/monitorings/oglyad-osnovnyh-polozhen-zakonoproyektu-pro-dezinformatsiyuta-poperedni-vysnovky-imi-i31315. [in Ukrainian]

Pro vnesennia zmin do Podatkovoho kodeksu Ukrainy shchodo opodatkuvannia podatkom na dodanu vartist elektronnykh posluh, shcho postachaiutsia nerezydentamy fizychnym osobam, mistse postachannia yakykh roztashovano na mytnii terytorii Ukrainy: proekt Zakonu Ukrainy 2019, № 2634 [On amendments to the Tax Code of Ukraine on value added tax on electronic services supplied by non-residents to individuals whose place of supply is located in the customs territory of Ukraine: draft Law of Ukraine] (2019). Retrived from: http://w1.c1.rada.gov.ua/pls/zweb2/webproc4_1?pf3511=67703. [in Ukrainian]

Pro media: proekt Zakonu Ukrainy 2019, № 2693 (2019). Retrived from: https://w1.c1.rada.gov.ua/pls/ zweb2/webproc4_1?pf3511=67812. [in Ukrainian]

Digital 2020: Global digital overview. Retrived from: https://datareportal.com/reports/digital-2020-globaldigital-overview.

Directive (EU) 2018/1808 of the European parliament and of the Council of 14 November 2018 (2018). Retrived from: https://eur-lex.europa.eu/legal-content/EN/TXT/?uri=celex:32018L1808.

European Commission and IT Companies announce Code of Conduct on illegal online hate speech (2016). Retrived from: https://ec.europa.eu/commission/presscorner/detail/en/IP_16_1937.

Hungarians stage Budapest protest against internet tax (2014). Retrived from: https://www.bbc.com/news/ world-europe-29783253.

Network Enforcement Act (Netzdurchsetzunggesetz, NetzDG), Federal Law Gazette I, p. 3352 ff. (2017). Retrived from: https://germanlawarchive.iuscomp.org/?p=1245.

\section{Анотація}

Новосельський I. Ф. Політико-правові засади функціонування нових медіа: світовий досвід та Україна. - Стаття.

У статті розглянуто особливості світового законодавчого досвіду у сфері правового регулювання онлайн-медіа. 3'ясовано, що вирішення питання правового забезпечення діяльності засобів масової інформації грунтується, з одного боку, на створенні окремих спеціальних норм для регулювання діяльності електронних медіа, з іншого - без створення галузевих законодавчих актів щодо саморегуляції відносин в мережі Інтернет. Зазначено, що міжнародне правове регулювання медіа відбувається в рамках умовних «східної» та «західної» моделей. Перша відрізняється домінантним контролем держави над медіапростором, мінімізацією саморегулювання відносин учасниками інформаційної діяльності. Друга закріплює за державою право регулювати та встановлювати розумний баланс між нормативно-правовою базою й інструментами саморегуляції. У рамках західної моделі запропоновано розгляд двох підходів щодо законодавчо визначеного впливу держави на функціонування засобів масової інформації. У межах підходу «держава-модератор» констатується залежність медіа від змін політичного ландшафту, збільшення урядового контролю над інформаційним простором, застосування методів фінансового тиску, процеси олігархізації медіа, підвищення непрозорості медіавласності (Угорщина, Чехія, Польща, Сербія). Другий підхід «держава-гарант» закріплює рекомендаційний характер норм діяльності конвергентних медіа та мінімізує втручання держави (Німеччина, Франція, Сполучені Штати Америки). Визначено, що проблемним аспектом законодавства європейського медійного простору залишається відсутність у країнах-членах Європейського Союзу узгодженого та послідовного підходу до видалення нелегального контенту в діяльності нових медіа. У результаті розгляду чинного законодавства України засвідчено суперечливість правового забезпечення діяльності засобів масової інформації. Констатовано розгалуженість системи законів щодо діяльності засобів масової інформації, задекларовані наміри узгодити її із законодавством європейських країн відповідно до низки зобов'язань. Проте стверджується, що відсутність дієвих механізмів захисту національного медіапростору України та побудови інформаційного середовища, здатного протистояти загрозам інформаційній безпеці, пропаганді в соціальних медіа, актуалізує необхідність національного регулювання відносин в Інтернеті.

Ключові слова: нові медіа, соціальні медіа, конвергентні медіа. 


\section{Summary}

Novoselskyi I. F. Political and legal principles of new media functioning: world and Ukraine experience.Article.

The article considers the peculiarities of the world legislative experience in the field of online media legal regulation. It is found that the solution of the issue of mass media activity legal support is based, on the one hand, on creation of separate special norms for regulation of electronic media activity, on the other - without creation of branch legislative acts on self-regulation of relations on the Internet. It is noted that the international legal media regulation takes place within the framework of the conditional "eastern" and "western" models. The first is characterized by the dominant control of the state over the media space, minimization of self-regulation of relations by participants in information activities. The second enshrines the right of the state to regulate and establish a reasonable balance between the legal framework and the instruments of self-regulation. Within the framework of the western model it is proposed to consider two approaches to the legally defined influence of the state on the media functioning. The approach "moderator-state" states the dependence of the media on changes in the political landscape, increased government control over the information space, the use of financial pressure, the process of oligarchization of the media, increasing the opacity of media ownership (Hungary, Czech Republic, Poland, Serbia). The second approach "guarantor-state" enshrines the recommendatory nature of the rules of convergent media and minimizes state intervention (Germany, France, USA). It is identified that the lack of a coordinated and consistent approach to the removal of illegal content in the activities of new media in the EU member states remains a problematic aspect of the legislation of the European media space. As a result of consideration of the current legislation of Ukraine it is proved the contradiction of legal support of activity of mass media. It is stated the branching of the system of laws on mass media activity and declared intentions to bring it in line with the legislation of European countries in accordance with a number of obligations. However, it is argued that the lack of effective mechanisms to protect Ukraine's national media space and build an information environment capable of countering threats to information security and social media propaganda highlights the need for national regulation of Internet relations

Key words: new media, social media, convergent media. 